\title{
The Mediating Effect of Top Management Support on the Relationship between Organizational Culture and Enterprise Risk Management Effectiveness among Malaysian Public Listed Companies: A Conceptual Framework
}

\author{
Mohd Faharizan HASSAN ${ }^{1 *}$ Ahmad Shukri YAZID ${ }^{2}$ \\ 1. Faculty of Economics and Management Sciences, Universiti Sultan Zainal Abidin,21300 Kuala Nerus, \\ Terengganu, Malaysia \\ 2. Faculty of Economics and Management Sciences, Universiti Sultan Zainal Abidin,21300 Kuala Nerus, \\ Terengganu, Malaysia
}

\begin{abstract}
Enterprise Risk Management (ERM) is believed as an effective risk management technique in managing risk within an organization and is fast becoming the best practice standard for an organization primarily for an entity that has high-risk exposure such as banking institutions. The purpose of this study is to develop the base knowledge and empirically test the relationship between organizational culture and ERM effectiveness. Also, an element of top management support also will be studied for determining the mediating effect of top management support on the relationship between organizational culture and ERM effectiveness. The data will be collected using a survey questionnaire and will be addressed to chief risk officers (CROs), chief internal auditors (CIAs) and chief financial officers (CFOs). This study tries to develop a conceptual framework by investigating the mediating effects of top management support on the relationship between organizational culture and ERM effectiveness among Malaysian public listed companies. Organizational culture expected to have direct effects and significantly influence ERM effectiveness. Also, top management support expected to mediates the relationship between organizational culture and ERM effectiveness.
\end{abstract}

Keywords: enterprise risk management, organizational culture, top management support, effectiveness

DOI: $10.7176 /$ RJFA/10-2-11

\section{Introduction}

Over the last fifteen years, the new risk management technique aimed to improve the traditional technique to risk management was introduced by proposing a holistic system that requires the organization to integrate different units and level within an organization known as enterprise risk management (ERM) (Arena, Arnaboldi, \& Azzone, 2010). The potential benefit of ERM in enhancing corporate governance and accountability has been agreed by different economic subjects, including both regulators and companies and this idea of risk management technique has been rapidly accepted (Arena, Azzone, Cagno, Silvestri, \& Trucco, 2014).

In Malaysia, Togok (2016) was conducted studies on ERM effectiveness by exploring the impact of six contingent factors which is involvement, structure, enterprise systems, culture, the tone from the top, and strategic role of ERM champion in influencing ERM effectiveness. The sample of this study comprised of 144 Malaysian public listed companies and the researcher found that culture, the tone from the top, and enterprise systems have direct effects and significantly influence ERM effectiveness in managing risk. The researcher found that there is an impact of culture on ERM effectiveness and the result shows that there is a significant association between culture and ERM effectiveness in managing risk within an organization.

Organizational culture and top management support as significant contextual factors in ERM effectiveness is scarcely studied. Many researchers have already developed several frameworks in this area (e.g., Hartnell, Ou, \& Kinicki, 2011; Laforet, 2016; Togok, 2016). However, these frameworks are not driven by organizational culture and top management support considerations simultaneously. A similar study on the impact of organizational and top management support on ERM effectiveness has been done by the past researcher (Togok, 2016). However, the researcher studies the other factors such as involvement, structure, enterprise systems, and the strategic role of ERM champion in the same framework in testing the effects on ERM effectiveness. On the other hand, the purpose of this current study is to test two variables which are organizational culture and top management support in influencing ERM effectiveness. In addition, in order to measure organizational culture, study done by Togok (2016) has adapts the model proposed by Wallach (1983) called Wallach's (1983) Model of 
Organizational Culture whereas this study adopts the Denison Model of Organizational Culture (1990) which focus on four dimensions including involvement, consistency, mission, and adaptability in measuring organizational culture's dimension.

Therefore the central determination of this study is to develop the base knowledge and empirically test the relationship between organizational culture components and ERM effectiveness. Also, this study also aims to identify the mediating effects of top management support on organizational culture and ERM effectiveness. By using Malaysian public listed companies as a sample, this study attempt to investigate these relationships.

\section{Literature Review}

\subsection{Enterprise Risk Management (ERM)}

Bogodistov \& Wohlgemuth (2017) has defined risk management as the process within the organization in managing risk by minimizing the return's unpredictability and ensure organizational sustainability. Among the process involved in risk management process are risk identification, risk assessment, and managing any possible events that might harm the organization as well as the other process in dealing with those possible events such as underlying internal communication, decision-making and monitoring processes. However, the scope and function of risk management have changed to adapt to the changes in economics and globalization process. Recently, risk management term has evolved from a narrow, insurance-based view that focused on evaluating risk from silo-based perspective to a holistic-based perspective; all risk encompassing view, commonly termed ERM (Pagach \& Warr, 2011). The practices of ERM is the new risk management practices and has started to gain attention globally as many organizations have started to implements ERM (Roslan \& Dahan, 2013). ERM was defined as the management of operational and financial risks simultaneously in order to maximize the costeffectiveness of risk management within the constraints of the organization's tolerance for risk (Kleffner, Lee, \& McGannon, 2003). There are two main industry-sanctioned ERM models, that is, COSO 2004 and ISO 31000:2009, that organizations refer to when implementing ERM programs (Karanja, 2017).

Pioneer researches on ERM was focused on the level of ERM adoption (Daud, Yazid, \& Hussin, 2010; Kleffner et al., 2003). Kleffner et al. (2003) has conducted a study on the application of ERM by Canadian companies and determine the roles of corporate governance in influencing the decision in implementing ERM. The data for the study was collected using survey questionnaires as well as telephone interview which addressed to the individual that responsible for risk management in companies which accounted for 118 sample sizes. The result found that out of 118 companies only 37 companies (31\%) have implemented ERM in their organization, whereas 34 companies (29\%) have investigated in adopting ERM in their organization. Unfortunately, 47 companies (40\%) don't consider at all in implementing ERM as their risk management technique in managing risk within their organization. Besides, pioneer research on ERM in Malaysia was conducted by a few researchers (Daud et al., 2010). The researchers study on the impact of Chief Risk Officer's appointment on ERM practice among Malaysian public listed companies. This study comprises of 86 public listed companies from the main board of Malaysian Bourse. The result shows that 37 companies (43\%) have implemented ERM within their organization whereas 49 companies (57\%) partially implementing ERM practice including the companies that still in the process of planning and investigating to implementing ERM practices.

Past studies on ERM also focus on the determinants of ERM adoption (Khan, Hussain, \& Mehmood, 2016; Paape \& Spekle, 2012), the effects of ERM practices on firm's value (McShane, 2018), the effects of ERM practices on organizational performance (Arnaboldi \& Lapsley, 2014; Rasid, Isa, \& Ismail, 2014), and internal audit involvement in ERM (Roslan \& Dahan, 2013; Zwaan, Stewart, \& Subramaniam, 2011). There is a limited number of studies that focused on ERM effectiveness (Liebenberg \& Hoyt, 2003). While most of the studies on ERM effectiveness were conducted in Western countries (Al-Amri \& Davydov, 2016; Arnold, Benford, Canada, \& Sutton, 2011; Gordon, Loeb, \& Tseng, 2009; Nair, Rustambekov, McShane, \& Fainshmidt, 2014; Paape \& Spekle, 2012), however, studies conducted among Asian countries still scarce and limited in number of studies. Laisasikorn \& Rompho (2014) studied the relationship between successful ERM systems on financial performance among Thai listed companies and found that there is a weak positive relationship between successful ERM system and financial performance. Also, Jalal, AlBayati, \& AlBuainain (2011) found that most of the banks have an effective ERM framework in place in their study on the factors that lead to ERM effectiveness among Bahrain banking sectors. 


\subsection{Organizational Culture and ERM Effectiveness}

Culture is essential because acting without knowing cultural forces might have unpredicted and unwanted outcomes (Ahmady, Nikooravesh, \& Mehrpour, 2016). Organizational culture has been recognized as an essential, influential factor in analyzing organizations in various contexts (Dauber, Fink, \& Yolles, 2012). Organizational culture can be defined as a complex set of values, beliefs, assumptions, and symbols that define the way that a firm conducts its business (Barney, 1986). Therefore, it is crucial to the organization to manage organizational culture because the individual in the organization responds to shared values and other aspects of organizational culture. Also, their action can have a significant impact on organizational effectiveness (Tsai, Chen, Chang, \& Lee, 2017). Moreover, knowing culture helped managers to implement suitable strategies to overcome the organization weaknesses.

A Turnbull Approach, which is a framework for effective risk management in financial institutions, was created as a new underlying approach to managing risk (Carey, 2011). The author of this framework has focused on the critical roles of culture as the factor that influences risk management effectiveness in financial institutions. Past studies on the factors that might influence risk management effectiveness has classified organizational culture as the critical success factor in managing risk effectively (Agoi, 2013; Banasadegh, Riahi, \& Davari, 2014; Yaraghi \& Langhe, 2011).

Coffey (2003) conducted a study on the effectiveness of companies involved in public sector housing construction in Hong Kong. The sample of the study comprised of 23 companies from housing construction in Hong Kong and the researcher found that a strong organizational culture has positive direct effects and significantly influence organizational effectiveness. Also, this study was supported by other studies that found similar results on the effect of organizational culture on organizational effectiveness (Ahmad, 2012; Zakari, Poku, \& Owusu-Ansah, 2013).

In his exploratory research, Ahmad (2012) had studied on the impact of organizational culture on performance management practices in Pakistan. By using a survey questionnaire, the researcher has collected the data from 42 respondents. The study found that organizational culture has a substantial impact on the performance management practices among employees in COMSATS Institute of Information Technology. Remarkably, the four traits of organizational culture in Denison's framework including adaptability, mission, consistency, and involvement have a significant impact on performance management practices at $99 \%$ confidence interval. Also, by using Denison's Organizational Model, Zakari (2013) conducted a study on the impact of organizational culture on organizational performance among the banking industry in Ghana. The sample of the study comprises 296 of respondents from nine banks in Ghana. The study found that there is a positive relationship between organizational culture and organizational performance. Moreover, the study also found that a mission culture trait is the most robust culture's dimensions that influence organizational performance in Ghana banking sector. As a conclusion, previous works of literature show that organizational culture has a substantial impact on organizational performance and organizational effectiveness. Therefore, this study will test the direct effect of organizational culture on ERM effectiveness.

\subsection{Top Management Support as Mediating Variable}

Top management support is the most popular variable that has been discussing extensively in ERM studies either in the study of ERM adoption or ERM effectiveness. Top management support can be defined as the commitment level of the senior management in an organization in particular project in term of their willingness and involvement to allocate the valuable organizational resource (Holland \& Light, 1999). Management support and commitment from top management are essential in many types of organization, and it becomes among the crucial factors in managing risk effectively.

Walker \& Shenkir (2018) proposed that the necessary condition for effective ERM implementation is the support from the board of directors (BODs) and top management, who are ultimately responsible for risk management within the organization. The BODs should regularly seek top management's responses to the questions regarding the top risk in the organization, the time horizon, and what has been taken by the organization in order to manage those risks. Also, the BODs also should discuss these questions among the members of the board and disseminate the message to the top management in order to maintain an effective risk management process. Then, the top management will be able to send a message to the entire organization. Walker \& Shenkir (2018) note that an ERM initiative is not able to succeed if do not engage with the strong support from senior management in an organization, and many studies (Banasadegh et al., 2014; Maina, Mbabazize, \& Kibachia, 2016; Makarova, 2014; Togok, 2016; Yaraghi \& Langhe, 2011) found that top management support is vital to the 
success of a variety of initiatives.

Yaraghi \& Langhe (2011) has implemented the grounded theory in order to identify the critical success factors in risk management systems. The result shows that top management is the first component of an organization should be aware in risk management systems because top management is among the most substantial factor in risk management systems. Educational background and competencies of the top management are among the critical factors in organizational because it will help the top management aware about risk management and also help the top management in planning a helpful strategy in the future. This theory has supported the study done previously by Ranong \& Phuenngam (2009) in Thailand financial institution which is the researchers found that support and commitment from top management are among the crucial factors for effective risk management procedures. Also, support and commitment from top management are also among the crucial factors for risk management success in the oil and gas sector in Iran (Banasadegh et al., 2014).

Recently, Maina et al. (2016) have conducted a study to determine the relationship between the level of project top management support on risk management effectiveness in public housing construction projects in Rwanda. The sample of this study consist of 108 staff members from Rwanda Social Security Board (RSSB), the Rwandan Ministries of Infrastructure and from City of Kigali $(\mathrm{CoK})$ who are directly involved in the project and the data was collected using survey questionnaire. The result shows that the low level of project top management support affects the effectiveness of risk management in public housing construction projects. The low level of top management support firstly affect the insufficient allocation of resource for risk management, and finally, the lack of effective decision making and stakeholder involvement by top management affected effective risk management in Batsinda Housing Project in Rwanda. The researchers also conclude that the top management should be committed to inclusive and transparent risk management and this clearly shows that top management support is very crucial in the success of risk management.

The mediating effects of top management support on the relationship between the independent variable and the dependent variable have been tested by the other researcher (Togok, 2016). The researcher found that organizational culture and tone from the top have direct effects and significantly influence ERM effectiveness in the study of the factors that influence ERM effectiveness among 144 Malaysian public listed companies as the sample of the study. Also, the researcher found that the tone from the top has partially mediated the relationship between organizational culture and ERM effectiveness. Therefore, this finding has motivated this study to test the same relationship; however, this current study is unique from the previous study because this current study will use different measurement in measuring organizational culture and top management support as compared to the previous study. This current study will adopt the Denison Model of Organizational Culture (1990) which focuses on four dimensions of culture including involvement, consistency, mission, and adaptability in measuring organizational culture's dimension. As a result, this study proposes to test the direct effect of top management support on ERM effectiveness. Also, this study will test the mediating effect of top management support on ERM effectiveness.

\section{Conceptual Framework}

This study will identify the extent of ERM practices among Malaysian public listed companies. Based on the previous literature, many factors influence the extent of ERM practices in Malaysia. In agreement with the previous literature discussed, figure 1 shows the proposed conceptual framework for this paper. The dependent variable for this study is ERM effectiveness which is measured the level of ERM effectiveness among the companies that implement ERM. Also, two variables namely organizational culture and top management support were included in order to determine the direct effects on ERM effectiveness. As a conclusion, this study proposed the conceptual framework to test the significant influence of organizational culture on ERM effectiveness and in the same time to identify the mediating effects of top management support between organizational culture and ERM effectiveness. 
Figure 1: Proposed Conceptual Framework

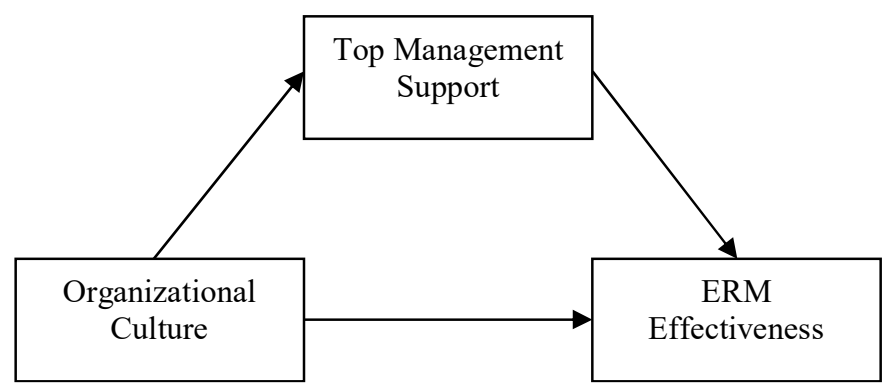

\section{Methodology}

\subsection{Sample and Data Collection Method}

Fourteen industries listed under Main Market of Bursa Malaysia which is categorized into closed-end funds, construction, consumer products, finance, hotel, industrial products, IPC, mining, plantations, properties, REITs, SPAC, technology, and trading/ services was the population considered in this study. As of November 25th, 2018, there are 799 companies listed under Main Market of Bursa Malaysia. Due to Main Market of Bursa Malaysia have regulated environment and likelihood of ERM adoption among public listed companies under Main Market of Bursa Malaysia are much higher, Main Market of Bursa Malaysia was selected by excluding ACE Market and LEAP Market (Togok, 2016). All the public listed companies that listed under Main Market of Bursa Malaysia were selected as a unit of analysis of this study. By using 10-points Likert scales, the data will be collected using survey questionnaire and will be addressed to chief risk officers (CROs), chief internal auditors (CIAs) and chief financial officers (CFOs) for each of the companies who have direct dealing with ERM practices.

\subsection{Instrumentation}

Table 1, 2, and 3 shows the questionnaire developed for this study. The instruments were adapted from the previous study that is focusing on organizational culture, top management support, and ERM effectiveness (Gillespie, Denison, Haaland, Smerek, \& Neale, 2018; Sax \& Torp, 2015; Togok, 2016). All items in the survey questionnaires that will be used in data collection are presented in table 1.

Table 1: Questionnaire Items for Enterprise Risk Management (ERM) Effectiveness Measurement

\begin{tabular}{|c|c|c|}
\hline Variables & Items in Survey Questionnaire & Sources \\
\hline \multirow{7}{*}{$\begin{array}{c}\text { Enterprise Risk } \\
\text { Management (ERM) } \\
\text { Effectiveness }\end{array}$} & $\begin{array}{l}\text { ERM enhances my organization ability to identify risk events } \\
\text { effectively }\end{array}$ & \multirow[t]{7}{*}{ Togok (2016) } \\
\hline & $\begin{array}{l}\text { ERM enhances my organization ability to assess risk events } \\
\text { effectively }\end{array}$ & \\
\hline & $\begin{array}{l}\text { ERM enhances my organization ability to manage risks within } \\
\text { its risk appetite }\end{array}$ & \\
\hline & $\begin{array}{l}\text { ERM enhances my organization ability to manage risks within } \\
\text { its risk tolerance level }\end{array}$ & \\
\hline & $\begin{array}{l}\text { ERM enhances my organization ability regarding the } \\
\text { achievement of entity objectives }\end{array}$ & \\
\hline & $\begin{array}{l}\text { ERM enhances my organization ability to minimize } \\
\text { unfavourable surprises and losses }\end{array}$ & \\
\hline & $\begin{array}{l}\text { ERM enhances my organization ability to optimize the potential } \\
\text { upside effects from the opportunities arising from the } \\
\text { uncertainties }\end{array}$ & \\
\hline
\end{tabular}


Table 2: Questionnaire Items for Top Management Support Measurement

\begin{tabular}{|c|c|c|}
\hline Variables & Items in Survey Questionnaire & Sources \\
\hline \multirow[t]{6}{*}{$\begin{array}{l}\text { Top Management } \\
\text { Support }\end{array}$} & $\begin{array}{l}\text { Top management actively seeks middle managers' opinions and } \\
\text { ideas on strategic issues }\end{array}$ & \multirow[t]{6}{*}{ Sax \& Torp (2015) } \\
\hline & $\begin{array}{l}\text { Top management is open to new ideas and initiatives from } \\
\text { ERM team member }\end{array}$ & \\
\hline & $\begin{array}{l}\text { Top management appreciate that middle manager's experiments } \\
\text { with new ideas and products }\end{array}$ & \\
\hline & $\begin{array}{l}\text { Top management appreciate that middle manager's experiments } \\
\text { on new products }\end{array}$ & \\
\hline & $\begin{array}{l}\text { Top management ensures that the interest of middle managers } \\
\text { are considered when making strategic decisions }\end{array}$ & \\
\hline & $\begin{array}{l}\text { The organization establish a risk management committee at } \\
\text { various level to measure the commitment of top management }\end{array}$ & \\
\hline
\end{tabular}

Table 3: Questionnaire Items for Organizational Culture Measurement

\begin{tabular}{|c|c|c|}
\hline Variables & Items in Survey Questionnaire & Sources \\
\hline \multirow[t]{12}{*}{$\begin{array}{l}\text { Organizational } \\
\text { Culture }\end{array}$} & $\begin{array}{l}\text { Decisions are usually made at the level where the best } \\
\text { information is available }\end{array}$ & \multirow[t]{12}{*}{ Gillespie et al. (2018) } \\
\hline & Working in this organization is like being part of a team & \\
\hline & My organization continuous invests in the skills of employees & \\
\hline & $\begin{array}{l}\text { There is a clear and consistent set of values in this organization } \\
\text { that governs the way we do business }\end{array}$ & \\
\hline & $\begin{array}{l}\text { When disagreements occur, we work hard to achieve solutions } \\
\text { that benefit both parties in the disagreement }\end{array}$ & \\
\hline & $\begin{array}{l}\text { People from different organizational units still share a common } \\
\text { perspective }\end{array}$ & \\
\hline & This organization is very responsive and changes easily & \\
\hline & Customer input directly influences our decisions & \\
\hline & $\begin{array}{l}\text { We view failure as an opportunity for learning and } \\
\text { improvement }\end{array}$ & \\
\hline & $\begin{array}{l}\text { My organization has a clear mission that gives meaning and } \\
\text { direction to our work. }\end{array}$ & \\
\hline & $\begin{array}{l}\text { The leadership has clearly stated the objectives we are trying to } \\
\text { meet }\end{array}$ & \\
\hline & $\begin{array}{l}\text { We have a shared vision of what this organization will be like } \\
\text { in the future }\end{array}$ & \\
\hline
\end{tabular}

\section{Conclusion}

The direct effects of organizational culture on organizational effectiveness had been studied by many of the scholars in organizational effectiveness studies (Denison, 1993; Denison \& Mishra, 1989). Unfortunately, there is a lack of study exploring the possible mediating effects of top management support on the relationship between organizational culture and ERM effectiveness. Organizational culture and top management support expected to have significant and direct effects on ERM effectiveness among Malaysian public listed companies. Also, the high involvement of top management support in an organization expected to have a strong impact and enhance the relationship between organizational culture and ERM effectiveness. In conclusion, organizational with strong top management support will help the organization in managing their risk effectively. Future studies 
on ERM effectiveness should focus on the other factors that might influence ERM effectiveness in an organization such as rewards and recognition, organizational structure, application of software in managing risks, and team member competency.

\section{References}

Agoi, M. A. (2013). Critical success factors and risk management procedures at Kenya Airports Authority (Master's thesis). University of Nairobi.

Ahmad, M. S. (2012). Impact of organizational culture on performance management practices in Pakistan. Business Intelligence Journal, 5(1), 50-55.

Ahmady, G. A., Nikooravesh, A., \& Mehrpour, M. (2016). Effect of organizational culture on knowledge management based on Denison model. Procedia - Social and Behavioral Sciences, 230, 387-395. http://doi.org/10.1016/j.sbspro.2016.09.049

Al-Amri, K., \& Davydov, Y. (2016). Testing the effectiveness of ERM: evidence from operational losses. Journal of Economics and Business, 87, 70-82. http://doi.org/10.1016/j.jeconbus.2016.07.002

Arena, M., Arnaboldi, M., \& Azzone, G. (2010). The organizational dynamics of Enterprise Risk Management. Accounting, Organizations and Society, 35(7), 659-675. http://doi.org/10.1016/j.aos.2010.07.003

Arena, M., Azzone, G., Cagno, E., Silvestri, A., \& Trucco, P. (2014). A model for operationalizing ERM in project-based operations through dynamic capabilities. International Journal of Energy Sector Management, 8(2), 178-197. http://doi.org/10.1108/IJESM-09-2012-0008

Arnaboldi, M., \& Lapsley, I. (2014). Enterprise-wide risk management and organizational fit: a comparative study. Journal of Organizational Effectiveness: People and Performance, 1(4), 365-377. http://doi.org/10.1108/JOEPP-09-2014-0056

Arnold, V., Benford, T., Canada, J., \& Sutton, S. G. (2011). The role of strategic enterprise risk management and organizational flexibility in easing new regulatory compliance. International Journal of Accounting Information Systems, 12, 171-188. http://doi.org/10.1016/j.accinf.2011.02.002

Banasadegh, Z., Riahi, F., \& Davari, A. (2014). A structural framework to assess the influence of CSFS on risk management case study: oil and gas sector in Iran. Research Journal of Applied Sciences, Engineering and Technology, 7(9), 1787-1793.

Barney, J. B. (1986). Organizational culture: can it be a source of sustained competitive advantage? The Academy of Management Review, 11(3), 656-665. http://doi.org/10.2307/258317

Bogodistov, Y., \& Wohlgemuth, V. (2017). Enterprise risk management: a capability-based perspective. The Journal of Risk Finance, 18(3), 234-251. http://doi.org/10.1108/ JRF-10-2016-0131

Carey, A. (2011). Effective risk management in financial institutions: the turnbull approach. Balance Sheet, 9(3), 24-27. http://doi.org/10.1108/02686901111151314

Coffey, V. (2003). The organisational culture and effectiveness of companies involved in public sector housing construction in Hong Kong. In CIB TG 23 International Conference (pp. 1-11).

Dauber, D., Fink, G., \& Yolles, M. (2012). A configuration model of organizational culture. SAGE Open, 1-16. http://doi.org/10.1177/2158244012441482

Daud, W. N. W., Yazid, A. S., \& Hussin, M. R. (2010). The effect of chief risk officer (CRO) on enterprise risk management (ERM) practices: evidence from Malaysia. International Business \& Economic Research Journal, 9(11), 55-64. http://doi.org/10.1108/14777830410531252

Denison, D. R. (1993). A theory of organizational culture and effectiveness (No. 728).

Denison, D. R., \& Mishra, A. K. (1989). Organizational culture and organizational effectiveness: a theory and some preliminary empirical evidence. In Academy of Management Best Papers Proceedings (pp. 168173).

Gillespie, M. A., Denison, D. R., Haaland, S., Smerek, R., \& Neale, W. S. (2018). Linking organizational culture and customer satisfaction: results from two companies in different industries. European Journal of Work and Organizational Psychology. http://doi.org/10.1080/13594320701560820

Gordon, L. A., Loeb, M. P., \& Tseng, C. Y. (2009). Enterprise risk management and firm performance: a 
contingency perspective. Journal of Accounting and Public Policy, 28(4), 301-327. http://doi.org/10.1016/j.jaccpubpol.2009.06.006

Hartnell, C. A., Ou, A. Y., \& Kinicki, A. (2011). Organizational culture and organizational effectiveness: a metaanalytic investigation of the competing values framework's theoretical suppositions. Journal of Applied Psychology, 96(4), 677-694. http://doi.org/10.1037/a0021987

Holland, C. P., \& Light, B. (1999). A Critical Success Factors Model For Enterprise Resource Planning Implementation. In Proceedings of the Seventh European Conference on Information Systems. http://doi.org/http://dx.doi.org/10.1109/52.765784

Jalal, A., AlBayati, F. S., \& AlBuainain, N. R. (2011). Evaluating enterprise risk management (ERM); Bahrain financial sectors as a case study. International Business Research, 4(3), 83-93. http://doi.org/10.5539/ibr.v4n3p83

Karanja, E. (2017). Does the hiring of chief risk officers align with the COSO/ISO enterprise risk management frameworks? International Journal of Accounting \& Information Management, 25(3), 274-295. http://doi.org/10.1108/IJAIM-04-2016-0037

Khan, M. J., Hussain, D., \& Mehmood, W. (2016). Why do firms adopt enterprise risk management (ERM)? empirical evidence from France. Management Decision, 54(8), 1886-1907. http://doi.org/10.1108/MD-092015-0400

Kleffner, A., Lee, R. B., \& McGannon, B. (2003). The effect of corporate governance on the use of enterprise risk management: evidence from Canada. Risk Management and Insurance Review, 6(1), 53-73. http://doi.org/10.1111/1098-1616.00020

Laforet, S. (2016). Effects of organisational culture on organisational innovation performance in family firms. Journal of Small Business and Enterprise Development, 23(2), 379-407. http://doi.org/10.1108/JSBED-022015-0020

Laisasikorn, K., \& Rompho, N. (2014). A study of the relationship between a successful enterprise risk management system, a performance measurement system and the financial performance of Thai listed companies. Journal of Applied Business and Economics, 16(2), 81-92.

Liebenberg, A. P., \& Hoyt, R. E. (2003). The determinants of enterprise risk management: evidence from the appointment of chief risk officers. Risk Management and Insurance Review, 6(1), 37-52. http://doi.org/10.1111/1098-1616.00019

Maina, N. P., Mbabazize, M., \& Kibachia, J. (2016). Evaluation of factors affecting effectiveness of risk management in public housing construction projects in Rwanda. case of Batsinda housing project. European Journal of Business and Social Sciences, 5(1), 85-101.

Makarova, V. A. (2014). The effectiveness of risk management implementation in Russian companies. World Applied Sciences Journal, 31(5), 833-839. http://doi.org/10.5829/idosi.wasj.2014.31.05.1660

McShane, M. (2018). Enterprise risk management: history and a design science proposal. The Journal of Risk Finance, 19(2), 137-153. http://doi.org/10.1108/JRF-03-2017-0048

Nair, A., Rustambekov, E., McShane, M., \& Fainshmidt, S. (2014). Enterprise risk management as a dynamic capability: a test of its effectiveness during a crisis. Managerial and Decision Economics, 35, 555-566. http://doi.org/10.1002/mde.2641

Paape, L., \& Spekle, R. F. (2012). The adoption and design of enterprise risk management practices: an empirical study. European Accounting Review, 21(3), 533-564. http://doi.org/10.1080/09638180.2012.661937

Pagach, D., \& Warr, R. (2011). The characteristics of firms that hire chief risk officers. The Journal of Risk and Insurance, 78(1), 185-211. http://doi.org/10.1111/j.1539-6975.2010.01378.x

Ranong, P. N., \& Phuenngam, W. (2009). Critical success factors for effective risk management procedures in financial industries: a study from the perspectives of the financial institutions in Thailand (Master's thesis). Umea University. Retrieved from http://www.divaportal.org/smash/record.jsf?pid=diva2\%3A233985\&dswid=9415

Rasid, S. Z. A., Isa, C. R., \& Ismail, W. K. W. (2014). Management accounting systems, enterprise risk management and organizational performance in financial institutions. Asian Review of Accounting, 22(2), 128-144. http://doi.org/10.1108/ARA-03-2013-0022 
Roslan, A., \& Dahan, H. M. (2013). Mediating effect of enterprise risk management on internal audit and organizational performance: a conceptual framework. International Journal of Commerce, Business and Management, 2(4), 212-215.

Sax, J., \& Torp, S. S. (2015). Speak up! enhancing risk performance with enterprise risk management, leadership style and employee voice. Management Decision, 53(7), 1452-1468. http://doi.org/10.1108/MD-10-20140625

Togok, S. (2016). Factors influencing the effectiveness of enterprise risk management (ERM) in public listed companies. University of Malaya.

Tsai, W.-H., Chen, H.-C., Chang, J.-C., \& Lee, H.-L. (2017). The internal audit performance: the effectiveness of ERM and it environments. In Proceedings of the 50th Hawaii International Conference on System Sciences (pp. 4898-4906). Hawaii.

Walker, P. L., \& Shenkir, W. G. (2018). Enterprise Risk Management : Frameworks, Elements, and Integration. Institute of Management Accountants. Retrieved from www.imanet.org

Wallach, E. J. (1983). Individuals and organization: the cultural match. Training and Development Journal, 12, $28-36$.

Yaraghi, N., \& Langhe, R. G. (2011). Critical success factors for risk management systems. Journal of Risk Research, 14(5), 551-581. http://doi.org/10.1080/13669877.2010.547253

Zakari, M., Poku, K., \& Owusu-Ansah, W. (2013). Organizational culture and organisational performance: empirical evidence from the banking industry in Ghana. International Journal of Business, Humanities and Technology, 3(1), 95-107. http://doi.org/10.1039/b111643f

Zwaan, L. de, Stewart, J., \& Subramaniam, N. (2011). Internal audit involvement in enterprise risk management. Managerial Auditing Journal, 26(7), 586-604. http://doi.org/10.1108/02686901111151323 